\title{
Inter- and Intraspecific Resistance Variability in Myrobalan Plum, Peach, and Peach-Almond Rootstock Using 22 Root-knot Nematode Populations
}

\author{
D. Esmenjaud', J.C. Minot, R. Voisin, J. Pinochet ${ }^{2}$, and G. Salesses ${ }^{3}$ \\ Laboratoire de Biologic des Invertébrés, Institut National de la Recherche Agronomique, B.P. 2078, \\ 06606 Antibes Cedex, France \\ Additional index words. Meloidogyne arenaria, Meloidogyne hapla, Meloidogyne hispanica, Meloidogyne incognita, \\ Meloidogyne javanica, Prunus amygdalus, Prunus cerasifera, Prunus persica

\begin{abstract}
Resistance variability was evaluated for five rootstock: three Myrobalan plum (Prunus cerasifera Ehr.) genotypes (P.1079, P.2175, and P.2032) grown from in vitro plantlets, one peach (P. persica (L.) Batsch 'GF 305') grown from seeds, and one peach-almond hybrid ( $P$. persica $\times P$. amygdalus Batsch 'GF 557') grown from rooted cuttings. Twenty-two root-knot nematode populations from different origins were used: Meloidogyne arenaria (Neal) Chitwood (six populations), $M$. incognita (Kofoid and White) Chitwood (eight populations), M.javanica (Treub) (four populations), $M$. hispanica Hirschmann (one population), M. hapla Chitwood (two populations), and an unclassified root-knot species (one population). The study was conducted under greenhouse conditions for 1 and 2 months. No galling or nematode reproduction was observed in P.1079 and P.2175, which should be considered immune; P.2032 showed the highest galling and nematode counts when inoculated with $M$. hispanica and $M$. javanica. In P.2032, a high proportion of males was recovered in populations that had a limited development. Because the populations of the first four Meloidogyne species reproduce by obligatory mitotic parthenogenesis, high sex ratio maybe the expression of a late form of resistance. Host suitability of ' $G F$ 305' was highly variable among $M$. arenaria and $M$. incognita populations. A lower relative variation was observed in M. javanica. 'GF 557' was resistant to $M$. arenaria and $M$. incognita except for one population of $M$. arenaria that was weakly aggressive and susceptible to $M$. javanica. Consequently, resistances specific to the genus Meloidogyne for the Myrobalan plum genotypes P.1079 and P.2175, specific to the nematode species for 'GF 557', and specific to the nematode population for ' $G F$ 305', were evidenced. This study indicates that, in rootstock selection procedures, it is important to test resistance to several populations within the same nematode species.
\end{abstract}

Root-knot nematodes cause significant economic damage in Prunus crops in many countries (Kochba and Spiegel-Roy, 1975; Pinochet et al., 1989; Scotto La Massèse et al., 1984; Sharpe et al., 1969). The three most widely distributed species in the Mediterranean region are Meloidogyne arenaria (Neal) Chitwood, M. incognita (Kofoid and White) Chitwood, and M. javanica (Treub). Of these, $M$. arenaria is the most common species in French orchards (Scotto La Massèse et al., 1990). Another important species, $M$. hispanica Hirschmann (Hirschmann, 1986), seems to be restricted to the southern part of the Iberian peninsula but is destructive when present.

Almond ( $P$. amygdalus Batsch) and peach can be heavily damaged by Meloidogyne spp. in temperate and Mediterranean areas (Kester and Grasselly, 1987; Layne, 1987; Minz and Cohn, 1962; Nyczepir, 1991; Pinochet et al., 1990; Scotto La Massèse, 1989). Controlling root-knot nematodes by preplant fumigation is costly and short-lived and may pollute the environment. Resistant rootstock, the best control alternative, have been studied since 1929 in the United States (Tufts, 1929). Unfortunately, several

Received for publication 10 Dec. 1992, Accepted for publication 23 Apr. 1993. M. Bongiovanni contributed most Meloidogyne populations. R. Poupet, J.P. Onesto, and P. Huguet provided technical assistance. The cost of publishing this paper was defrayed in part by the payment of page charges. Under postal regulations, this paper therefore must be hereby marked advertisement solely to indicate this fact. ${ }^{1}$ Research hematologist.

Reseach hematologist. Current address: Dept. de Patologia Vegetal, Institut de Recerca i Tecnologia Agroalimentaries, Ctra. de Cabrils s/nT, 08348, Cabrils, Barcelona, Spain.

${ }^{3}$ Research geneticist. Current address: Station de Recherches fruitières, INRA, B.P. 81, 33883 Villenave d'Omon Cedex, France. resistant rootstock released in the United States (Kester and Asay, 1986; Ramming and Tanner, 1983; Sharpe et al., 1969; Sherman et al., 1981) or in Israel (Kochba and Spiegel-Roy, 1976) in the last 30 years are not well adapted to the climatic and edaphic conditions of southern Europe because of their susceptibility to calcareous and heavy soils or their low chilling requirements. Consequently, studies to find more adapted sources of resistance for the creation of stone fruit stocks, especially by inter-and intraspecific hybridization, have been undertaken in France in the same period (Bernhard, 1962; Bernhard et al., 1979; Renaud et al., 1988), and more recently in Spain (Felipe, 1989; Felipe et al., 1989).

One source of root-knot nematode resistance is Myrobalan plum (Scotto La Massèse et al., 1990), but the host response of Myrobalan plum genotypes ranges from susceptible to highly resistant to M. arenaria (Esmenjaud et al., 1992). Evaluations of the resistance range are generally based on evaluations of a single population per root-knot nematode species (Marull et al., 1991; Pinochet et al., 1989, 1990) or on a mixture of various populations belonging to the same species (Marull and Pinochet, 1991; Scotto La Massèse et al., 1984). Recently, multiple inoculations with many populations including several root-knot species are being performed in resistance verification tests (J. Pinochet, unpublished data). From these results, nematode resistance cannot be considered clearly as species specific in Prunus spp. So far, no study of the response of a genotype to many distinct Meloidogyne populations and species has been conducted. The purpose of this research was to determine the inter- and intraspecific variability of rootknot resistance of three experimental Myrobalan plum genotypes, together with a resistant peach-almond and a susceptible peach, to 22 Meloidogyne populations of diverse geographical and host origin. 


\section{Materials and Methods}

Plant material. Three Myrobalan plum genotypes were chosen for this study, of which P. 1079 and P.2175 are highly resistant to the 'Monteux' isolate of $M$. arenaria (Scotto La Massèse et al., 1990). The third Myrobalan plum genotype, P.2032, is susceptible to the same isolate. The peach 'GF 305' (susceptible) (Pinochet et al., 1989; Scotto La Massèse et al., 1984), and the peach-almond hybrid 'GF 557' (resistant to $M$. arenaria and $M$. incognita) (Philis, 1989; Scotto La Massèse, 1989) were used as controls. These two rootstock were obtained from the Institut National de la Recherche Agronomique (INRA), France, and are used widely in Europe (Kester and Grasselly, 1987; Layne, 1987). The three Myrobalan plum genotypes were grown in vitro (Esmenjaud et al., 1993). 'GF 305' was obtained from seeds and 'GF 557' was propagated from hardwood cuttings.

Nematode populations. Twenty-two root-knot nematode populations from various geographical origins were used (Table 1). All populations except 'Taragona', 'Aigues-Mortes', 'Landes', and 'Reus + California' were isolates (reared from a single egg mass). The populations avirulent to the $M i$ gene of resistant tomato cultivars were maintained on 'St Pierre' tomato (Lycopersicon esculentum Mill.), and virulent populations were maintained on 'Piersol' tomato bearing the Mi geneforresistance to Meloidogyne. Meloidogyne $M i$ virulent 'Calissanne' and $M i$ virulent 'Côte d'Ivoire' were selected from the avirulent wild-type isolates, respectively, by continuous multiplication on 'Piersol' for $>30$ generations (Jarquin-Barberena et al., 1991; Roberts et al., 1990). The 'Pikine' (Netscher, 1977) and 'Valbonne' isolates are naturally virulent to the tomato cultivars bearing the $M i$ gene.

Experimental procedure. The three Myrobalan plum genotypes were propagated and rooted on Murashige and Skoog medium at $22 \mathrm{C}$ with a 16 -h photoperiod. The plantlets were transplanted into sterilized 1 fine sand: 1 perlite $(\mathrm{v} / \mathrm{v})$ substrate in tanks $(50 \times 30 \times$ $15 \mathrm{~cm}$ ), then grown for 2 weeks in an acclimation chamber at 20-
22C $\left(70 \%\right.$ to $90 \%$ relative humidity, $100 \mathrm{~W} \cdot \mathrm{m}^{-2}$, 16-h photoperiod, and 2 weeks in the greenhouse at 23 to $27 \mathrm{C}$. Plantlets ranging from 6 to $7 \mathrm{~cm}$ high were then transplanted into 0.25 -liter individual containers filled with a sterilized potting medium of 4 fine sand: 1 loamy soil $(\mathrm{v} / \mathrm{v})$. Following the recommendation of Wallace (1969), a sand particle size of 0.1 to $0.5 \mathrm{~mm}$ was used. 'GF 305' seeds were stratified in perlite trays at $4 \mathrm{C}$ for 90 days and then moved to a greenhouse held at a mean of $25 \mathrm{C}$ to induce germination. 'GF 557' cuttings were treated for $10 \mathrm{sec}$ with a $50 \%$ alcohol solution that contained 2000 ppm of indolebutyric acid. Cuttings were planted into 0.2-liter containers filled with a sterilized sandpeat mixture. Germinated seeds and rooted cuttings were washed free of substrate before final transplantation into 1 -liter containers filled with the same substrate as used for Myrobalan plum plantlets. All containers were irrigated every 2 days with a $7.5 \mathrm{~N}$ $11.5 \mathrm{P}_{2} \mathrm{O}_{5}-7.5 \mathrm{~K}_{2} \mathrm{O}$ nutrient solution at $3 \mathrm{~g} \cdot$ liter $^{-1}$, completed with trace elements (Algoflash; Algochimie, Tours, -France) and grown between April and July at a mean of 25C (extremes 22 to 28C). Nematode juveniles (J2) were obtained in a mist chamber from tomato roots previously inoculated with the various tested isolates. Ten thousand J2, 24 to 72 hold, were deposited per plant at the base of the stem into four 2-cm-deep holes $1 \mathrm{~cm}$ from the stem. This level of inoculum was chosen based on a previous methodological study on the same Myrobalan plum genotypes (Esmenjaud et al., 1993) to allow a better differentiation of population multiplication without inducing major intraspecific competition.

Ten seedlings of 'St Pierre' and 'Piersol' tomatoes, respectively susceptible and resistant ( $\mathrm{Mi}$ gene) to Meloidogyne, were inoculated at the three-leaf stage in 50-ml plastic tubes on the same date as Prunus plantlets with $250 \mathrm{~J} 2$ of each population. After 45 days, the tomatoes were harvested. The identity of the nematode populations was verified via their isoesterase phenotype (Janati et al., 1982) and their reaction to both tomato cultivars. Their good vigor was also confirmed from the estimation of the number of galls formed by each population on the same tomato plants.

Table 1. General information on the origin of 22 Meloidogyne populations used in our Prunus evaluations.

\begin{tabular}{|c|c|c|c|}
\hline Nematode & Population & Origin & Host \\
\hline \multirow{6}{*}{ M. arenaria } & 1) Monteux & Provence, France & Tomato \\
\hline & 2) Ain Taoujdate & Meknes, Morocco & Peach \\
\hline & 3) Los Palacios & Cataluña, Spain & Carnation \\
\hline & 4) Taragona & Cataluña & Melon \\
\hline & 5) Portugal & Portugal & Unknown \\
\hline & 6) San Benedetto & Toscania, Italy & Unknown \\
\hline \multirow[t]{8}{*}{ M. incognita. } & 7) $M i$ avirulent Calissanne & Provence & Tomato \\
\hline & 8) $M i$ avirulent Côte d'Ivoire & Abidjan, Ivory Coast & Tomato \\
\hline & 9) $M i$ virulent Calissanne & INRA $^{z}$ & Tomato \\
\hline & 10) $M i$ virulent Côte d'Ivoire & INRA & Tomato \\
\hline & 11) Valbonne & Provence & Tomato \\
\hline & 12) Aigues-Mortes & Languedoc, France & Asparagus \\
\hline & 13) USA 83 & North Carolina & Unknown \\
\hline & 14) Landes & Gascogne, France & Soybean \\
\hline \multirow[t]{4}{*}{ M. javanica } & 15) Oualidia & Morocco & Peach \\
\hline & 16) USA 72 & North Carolina & Unknown \\
\hline & 17) Reus + California & Cataluña and California & Almond + unknown \\
\hline & 18) Reunion & Reunion, Indian Ocean & Peach \\
\hline M. hispanica & 19) Sevilla & Seville, Spain & Peach-almond hybrid \\
\hline \multirow[t]{2}{*}{ M. hapla } & 20) La Mole & Provence & Grapevine \\
\hline & 21) Canada & Canada & Unknown \\
\hline Meloidogyne sp. & 22) Pikine & Dakar, Senegal & Tomato \\
\hline
\end{tabular}

${ }^{\bar{x}}$ INRA $=$ Institut National de la Recherche Agronomique. 
Genotype P. 1079 was exposed to all the populations. P.2175 was exposed to 15 populations $(1,2,3,6,7,8,9,10,11,15,16,19$, $20,21,22)$ and P.2032 to 16 populations $(1,2,3,6,7,8,9,10,11$, $12,13,14,16,19,20,22)$ representing all the tested species (Table 1). There were 10 replications of each population-genotype combination plus 10 uninoculated plantlets of each genotype. Pots inoculated with the same population were arranged in a completely randomized design, ordered side by side on a single greenhouse bench. Groups of pots inoculated with a given population were separated from those inoculated with other populations by transparent splash screens. Four replications were harvested 30 days and the six remaining replications were harvested 60 days after inoculation. Peach and peach-almond rootstock (five replications) arranged similarly to Myrobalan plum genotypes were exposed to all populations (except $M i$ avirulent 'Côte d' Ivoire' in 'GF 305') and harvested 60 days after inoculation. Five replications of each control rootstock were uninoculated.

At harvest, plant roots were carefully washed individually under tap water and over a small bucket. Root-gall indexes were recorded according to a $\mathrm{O}$ to 5 scale (Barker, 1985)- $0=$ no gall; $1=1 \%$ to $10 \%$ of root-system galled; $2=11 \%$ to $30 \% ; 3=31 \%$ to $70 \%$; $4=71 \%$ to $90 \%$; 5 is $>90 \%$-completed with 0.5 steps when galling was estimated to be at the limit between two classes. After the ratings, the root system was frozen at $-20 \mathrm{C}$ until nematodes were extracted. Soil nematodes from each plant were recovered from each bucket by three sedimentations, each followed by sieving on a 40- $\mu$ m-pore sieve (Dalmasso, 1966). Frozen root systems were transferred to a refrigerator (5C) to be thawed progressively. Root nematodes were extracted using an ultra grinder (20,000-rpm) for $2 \mathrm{sec}$ then a 250 - $\mu \mathrm{m}$-pore sieve to collect the freed stages into a beaker. Nonground roots and rootlets were recovered and were ground two more times. Then-the content of the beaker was centrifuged twice (Jenkins, 1964). Females, males, J3$\mathrm{J} 4, \mathrm{~J} 2$, and eggs were counted under a binocular microscope. Data were tested using a one-way analysis of variance. Nematode densities were $\log _{10}(\mathrm{x}+1)$ transformed for analysis (Noe, 1985). Means were compared by Newman-Keuls multiple range test at $P \leq 0.05$.

\section{Results}

Myrobalan plum. The genotypes P. 1079 and P.2175 were completely free of galls and developing or adult nematodes in the roots or the soil after 1 and 2 months.

At 1 month, P.2032 root galling was limited and variability among plants treated with different populations was low. Meloidogyne hispanica 'Sevilla' and M. javanica 'Oualidia' populations induced the highest gall index, whereas $M$. arenaria, five $M$. incognita populations, and the two other $M$. javanica populations gave intermediate values. Two $M$. incognita and the $M$. hapla and 'Pikine' populations gave the significantly lower indexes (Table 2). At 2 months, gall ratings were similar or decreased with $M$. arenaria and with $M$. incognita, except 'Valbonne', and the populations 'USA 83' and 'Landes' that were very low at 1 month. The three $M$. javanica populations reached a high and similar galling level and $M$. hispanica induced a gall index significantly higher than any other population. Low and no galling were observed for 'Pikine' and M. hapla populations respectively. In 'Calissanne' and 'Côte d'Ivoire', $M i$ virulent and avirulent populations had similar gallings on the two dates (Table 2).

At 2 months, total nematode counts (root+ soil) were closely related to gall indexes (Table 2). In 'Calissanne' and 'Côte d'Ivoire', $M i$ virulent and avirulent populations had similar total nematode counts. At 1 month, there were many more males than females, except in M. hispanica, M. javanica, and M. hapla (La Mole, Fig. $1)$. At 2 months, $M$. hispanica and $M$. javanica had the most females. Meloidogyne javanica and 'Landes' populations had the fewest males at 1 month but had more females at 2 months. Moreover, in each of the $M$. arenaria, $M$. incognita, and $M$. javanica species considered separately, most populations with many females had proportionately fewer males than populations with few females. In $M$. javanica populations, it was particularly evident that the number of females was inversely proportional to the number of males.

Peach and peach-almond. Important differences in the host suitability y of the susceptible control 'GF 305 ' to $M$. arenaria and $M$. incognita populations were observed (Fig. 2). There were few 'Ain Taoujdate' and 'Portugal' in $M$. arenaria, and $M i$ avirulent 'Calissanne', $M i$ virulent 'Calissanne', and 'Aigues-Mortes' in $M$. incognita.. In contrast, 'Taragona' and 'San Benedetto' in M. arenaria, and $M i$ virulent 'Côte d'Ivoire', 'Valbonne', and 'Landes' in $M$. incognita reached significantly higher nematode densities in relation to most tested populations. Although based on fewer populations, total counts and, consequently, intraspecific variations were lowest in $M$. javanica. Reproduction of $M$. hapla and 'Pikine' populations was incipient. In 'GF 557', the most nematodes were obtained for three $M$. javanica populations followed by 'Taragona', the fourth M. javanica population ('USA 72'), 'Pikine', and 'Landes' (Fig. 2). Other populations reached very low levels. In both rootstock, $M i$ avirulent 'Calissanne' and $M i$ virulent 'Calissanne' had equivalent counts. In 'GF 557', Mi virulent and avirulent 'Côte d'Ivoire' also had similar counts.

Table 2. Gall index and total nematode counts per plant in the Prunus cerasifera genotype P.2032, 1 and 2 months after the inoculation of 17 Meloidogyne populations.

\begin{tabular}{|c|c|c|c|}
\hline \multirow[b]{2}{*}{ Nematode } & \multicolumn{2}{|c|}{ Gall index ${ }^{2}$} & \multirow{2}{*}{$\begin{array}{l}\text { Total nematodes/ } \\
\text { plant at } 2 \text { months }\end{array}$} \\
\hline & 1 month & 2 months & \\
\hline \multicolumn{4}{|l|}{ M. arenaria } \\
\hline Monteux & $1.13 b^{y}$ & $1.00 \mathrm{~cd}$ & $132 c^{x}$ \\
\hline Ain Taoujdate & $1.45 \mathrm{~b}$ & $1.58 \mathrm{C}$ & $84 \mathrm{~cd}$ \\
\hline Los Palacios & $1.45 \mathrm{~b}$ & $0.58 \mathrm{~d}$ & $52 \mathrm{~d}$ \\
\hline San Benedetto & $1.20 \mathrm{~b}$ & $0.90 \mathrm{~cd}$ & $130 \mathrm{C}$ \\
\hline \multicolumn{4}{|l|}{ M. incognita } \\
\hline$M i$ avirulent Calissanne & $1.00 \mathrm{~b}$ & $0.83 \mathrm{~cd}$ & $45 \mathrm{~d}$ \\
\hline$M i$ avirulent Côte d'Ivoire & $1.00 \mathrm{~b}$ & $0.58 \mathrm{~d}$ & $176 \mathrm{c}$ \\
\hline$M i$ virulent Calissanne & $1.00 \mathrm{~b}$ & $0.75 \mathrm{~d}$ & $38 \mathrm{~cd}$ \\
\hline$M i$ virulent Côte d'Ivoire & $1.00 \mathrm{~b}$ & $0.92 \mathrm{~cd}$ & $98 \mathrm{~cd}$ \\
\hline Valbonne & $1.00 \mathrm{~b}$ & $1.42 \mathrm{c}$ & $262 \mathrm{c}$ \\
\hline USA 83 & $0.13 \mathrm{c}$ & $0.50 \mathrm{~d}$ & $116 \mathrm{~cd}$ \\
\hline Landes & $0.13 \mathrm{c}$ & $1.10 \mathrm{~cd}$ & $1035 \mathrm{~b}$ \\
\hline \multicolumn{4}{|l|}{ M. javanica } \\
\hline Oualidia & $1.95 \mathrm{a}$ & $2.10 \mathrm{~b}$ & $1140 \mathrm{~b}$ \\
\hline USA 72 & $1.00 \mathrm{~b}$ & $2.50 \mathrm{~b}$ & $1572 \mathrm{~b}$ \\
\hline Reus + California & $1.00 \mathrm{~b}$ & $2.42 \mathrm{~b}$ & $851 \mathrm{~b}$ \\
\hline \multicolumn{4}{|l|}{ M. hispanica } \\
\hline Sevilla & $1.75 \mathrm{a}$ & $4.00 \mathrm{a}$ & $10900 \mathrm{a}$ \\
\hline \multicolumn{4}{|l|}{ M. hapla } \\
\hline La Mole & $0.00 c$ & $0.08 \mathrm{e}$ & $1 \mathrm{e}$ \\
\hline \multicolumn{4}{|l|}{ Meloidogyne sp. } \\
\hline Pikine & $0.00 c$ & $0.45 \mathrm{~d}$ & $0 \mathrm{e}$ \\
\hline
\end{tabular}

${ }^{\mathrm{T}}$ Gall index ratings: 0 is no gall; 5 is $>90 \%$ of root system galled.

${ }^{y}$ Mean separation within columns by Newman-Keuls multiple range test at $P<0.05$.

${ }^{x}$ Actual data are presented but data were transformed to $\log _{10}(x+1)$ for analysis. 


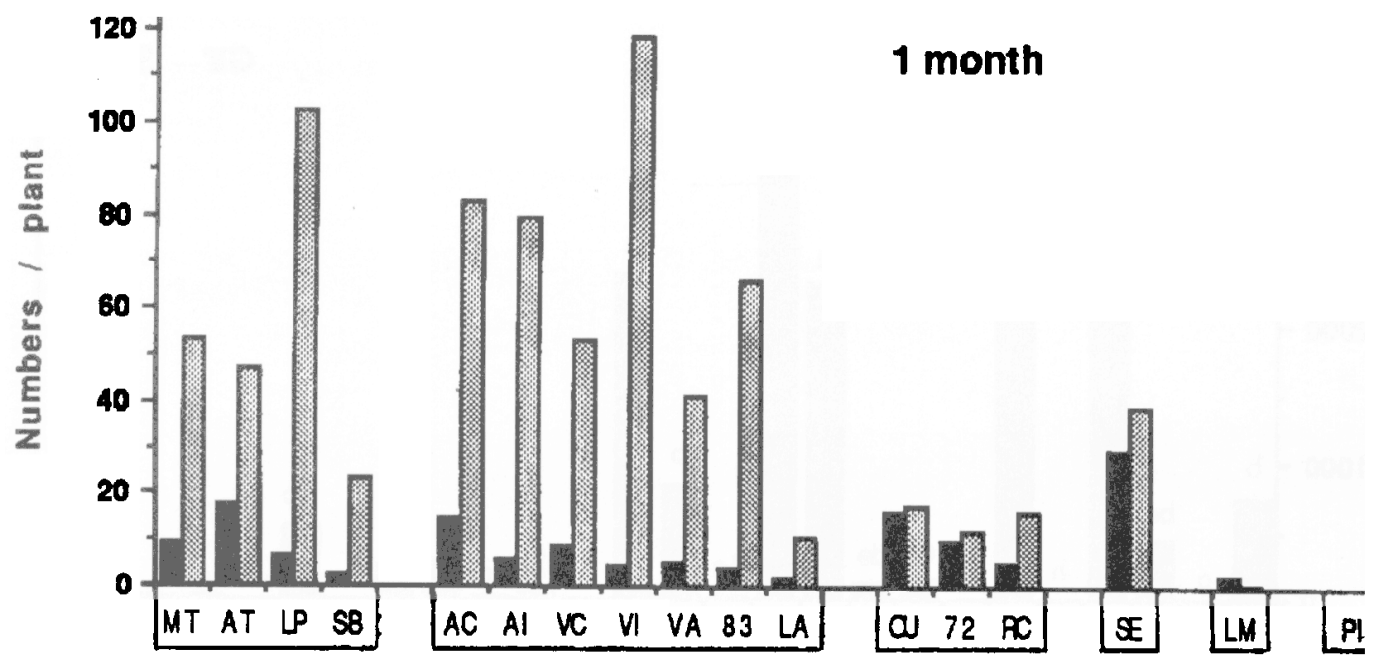

D females 墙 males

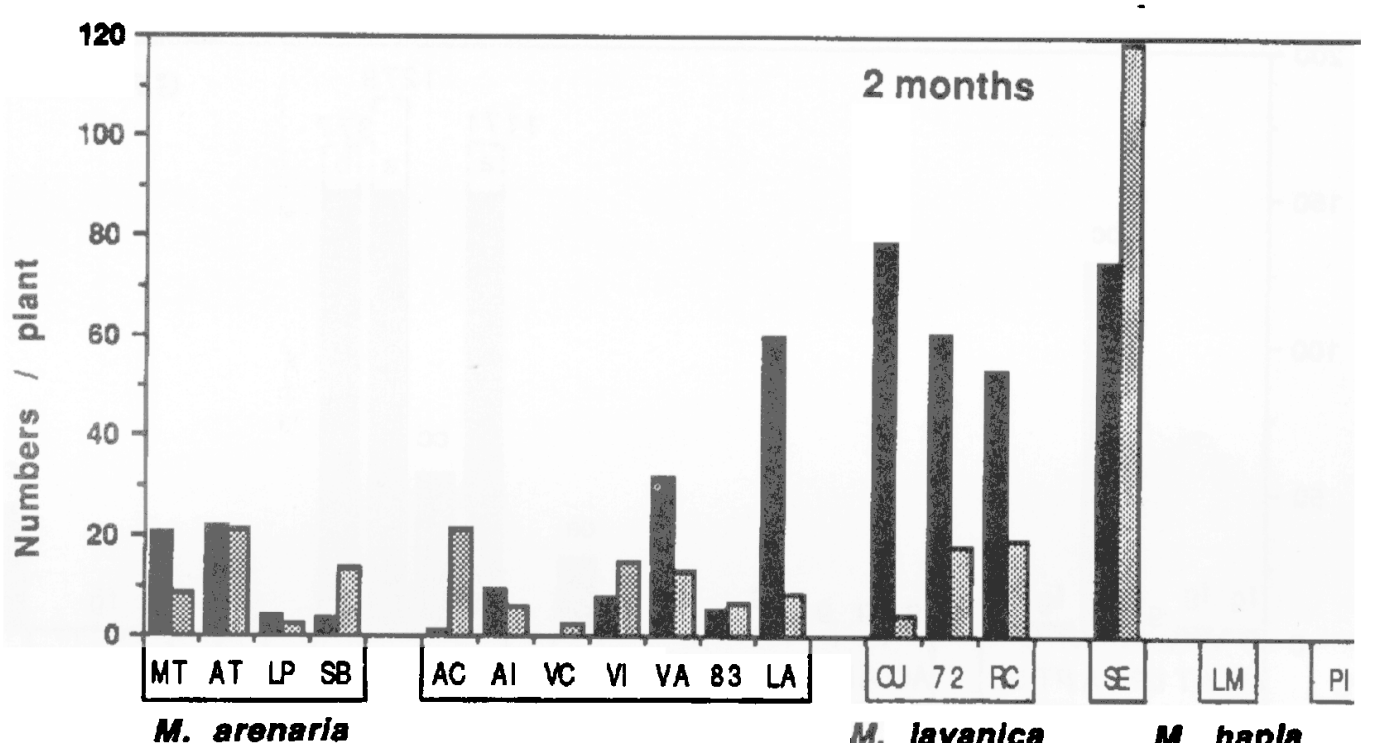

Fig. 1. Female and male numbers of Meloidogyne in roots of Prunus cerasifera genotype P.2032, 1 and 2 months after the inoculation of 17 populations. MT = 'Monteux', $\mathrm{AT}=$ 'Ain Taoujdate', $\mathrm{LP}=$ 'Los Palacios', $\mathrm{SB}=$ 'San Benedetto', $\mathrm{AC}=M i$ avirulent 'Calissanne', $\mathrm{AI}=M i$ avirulent 'Côte d'Ivoire', VC = Mi virulent 'Calissanne', $\mathrm{VI}=$ Mi virulent 'Côte d'Ivoire', VA = 'Valbonne', $83=$ 'USA 83', LA = 'Landes', OU = 'Oualidia', $72=$ 'USA 72', RC = 'Reus + California', SE = 'Sevilla', LM $=$ 'La Mole', PI $=$ 'Pikine'.

\section{Discussion}

The Myrobalan plum genotypes P. 1079 and P.2175 have a very wide and similar resistance range. Considering that no galls or nematodes in any stage were detected, both genotypes should be considered immune. The same resistance genes may be involved in the two genotypes, or both genotypes could have different resistance genes but still have a high level of cosmopolitan resistance across nematode species and isolates. Previous tests of more than 100 intraspecific crosses between P. 1079 and susceptible genotypes demonstrated that the genes involved in the resistance of this genotype to a particular population of $M$. arenaria are dominant. Crosses of P.2175 with the same susceptible genotypes, using the same nematode population, gave at least 50\% highly resistant hybrids (Scotto La Massèse et al., 1990). Consequently, this latter genotype should be considered heterozygous for the same or different dominant genes.

P.2032 susceptibility varied considerably with the Meloidogyne populations. Its host suitability was excellent for M. hispanica, good for M. javanica and the 'Landes' population of $M$. incognita, and moderate for $M$. arenaria and most $M$. incognita populations. P.2032 was not a host for the M. hapla and 'Pikine' populations.

Because of the homogeneity of plantlets obtained from in vitro propagation, interesting data were obtained on the host-parasite relationship in this genotype. At 1 month, the higher sex ratio (males : females) observed in $M$. arenaria and $M$. incognita may indicate either a slower development of these two species compared with $M$. javanica and $M$. hispanica, considering that males appear earlier than females, or a lower host suitability of the 

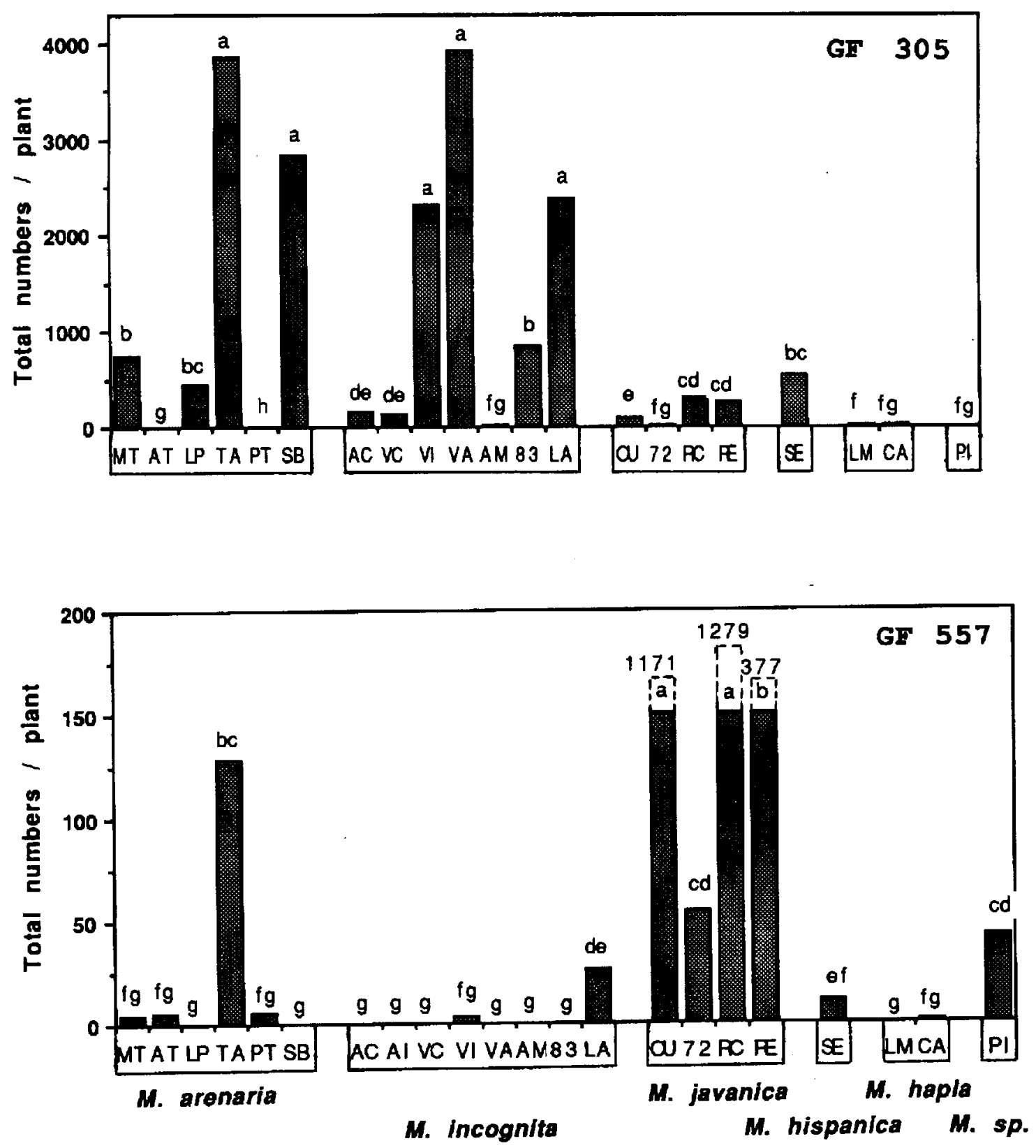

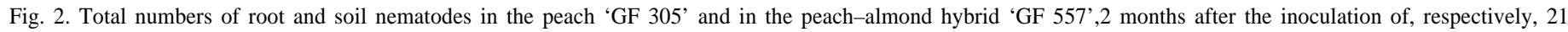

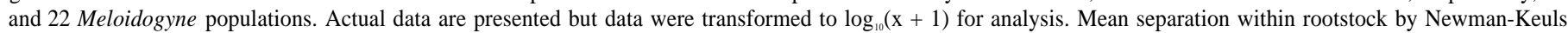

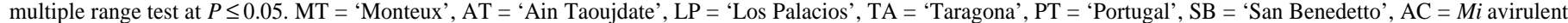

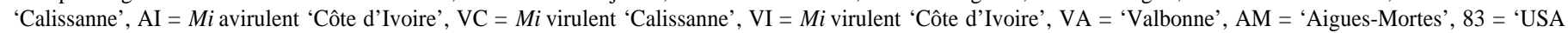

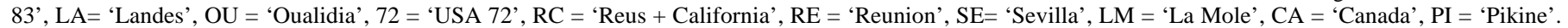

genotype for these latter species, or a combined action. At 2 months, a high proportion of males was generally recovered in populations that had a limited development. As the populations we used, except those of $M$. hapla, reproduce by obligatory mitotic parthenogenesis (Triantaphyllou, 1971, 1981), males are useless for nematode multiplication and, consequently, a high sex ratio may be considered a complementary criterion of resistance. High sex ratios are observed when a given population is submitted to unfavorable developmental conditions (Orion, 1973; Bergé et al., 1974) and indicate a particular form of resistance. This phenomenon occurs in the nematode cycle later than the hypersensitive reaction induced by $M$. incognita juveniles (Fresno, 1975) on 'Nemaguard' or 'Okinawa' or the "walling-off' process (Malo, 1967) that prevents the complete development of $M$. javanica larvae on the same rootstock. However, in the $M$. hispanica the population, high numbers of males and females were observed simultaneously. For this population, which produced much higher total numbers than others at 2 months, the high sex ratio is presumably not the direct effect of the plant, but the consequence of the intraspecific nematode competition in the roots.

In 'GF 305', large variations were observed within each nematode species and these variations explain why this rootstock was found to be resistant to M. arenaria by Marull et al. (1991) and susceptible by Scotto La Massèse et al. (1984). Such variable response of 'GF 305' has not been reported for $M$. javanica (Pinochet et al., 1989; Scotto La Massèse, 1984), a result that would confirm similar results obtained in our study.

In resistant P. 1079 and P.2175, no virulent population was 
detected; whereas, in 'GF 557', considered as resistant to $M$. arenaria and $M$. incognita, a virulent (although rather weakly) population in $M$. arenaria was observed. The susceptibility of this latter rootstock to $M$. javanica (Philis, 1989; Scotto La Massèse, 1989) was confirmed here from a sample of four populations. 'GF 557 ' is a natural hybrid between almond and resistant 'Shalil' peach (Kester and Grasselly, 1987). Consequently, the genes involved in the resistance of this species act against most of the populations of $M$. arenaria, M. incognita, and M. hapla but not ,or at least less, against $M$. javanica populations. Other sources of resistance used for peach ('Yunan', 'Stribling's 37', and 'Bokhara' ) (Burdett et al., 1963; Chitwood et al., 1952; Day and Tufts, 1939; Havis et al., 1950) also were susceptible to M. javanica. Sources of resistance selected later, such as $P$. davidiana or 'Okinawa', are resistant (Sharpe, 1957; Burdett et al., 1963; Sharpe et al., 1969; Sherman et al., 1981) to $M$. arenaria, $M$. incognita, and $M$. javanica. Resistance to $M$. incognita in the above sources is monofactorial and dominant, whereas resistance to $M$. javanica seemed conditioned by at least two dominant genes (Sharpe et al., 1969). It would be interesting to test the same range of populations, and particularly the most aggressive of them, on some of these peach selections to see if the genes involved in 'GF 557' resistance to $M$. arenaria and $M$. incognita might also be involved in the resistance of $P$. davidiana or 'Okinawa' to these nematode species. Nevertheless, if similar patterns of resistance range were obtained, a complete genetic study would be necessary to establish that the genes involved are identical.

In the resistant genotypes P. 1079 and P.2 175, as in P. davidiana and 'Okinawa', no difference between $M$. javanica and the other species was observed. Testing the Florida $M$. incognita population that overcomes the resistance of Nemaguard $(P$. davidiana $\times$ Chinese peach) and 'Okinawa' rootstock (Sharpe and Perry, 1967; Sharpe et al., 1969; Sherman and Lyrene, 1983; Sherman et al., 198 1) on resistant Myrobalan plums would provide preliminary data to relate the genes involved in both resistances.

Finally, our study concludes that the response of Prunus selections to root-knot nematodes can be specific either to the Meloidogyne genus, as with P. 1079 and P.2175, or it can be specific to the nematode species, as with 'GF 557' ( 'Shalil' ) and, to a lesser extent with P.2032, or the plant response can be specific to the nematode population within the same nematode species, as with 'GF 305'. These results indicate the importance of testing resistance sources to a wide range of populations in rootstock selection.

Because of the soil extraction technique, eggs were not recovered from the soil and, thus, the ratio of the final population to the initial population (FP : IP) is underestimated, On 'GF 305', the higher FP : IP ratio obtained by Pinochet et al. (1989) in similar tests is mainly due to running the tests for 4 instead of 2 months, as we did here. For the same population, a direct comparison of nematode numbers produced in P.2032, 'GF 305', and 'GF 557' may not be valuable because the plantlets were derived from different types of multiplication (in vitro propagation, seeds, and cuttings). In $M$. incognita, for each pair of 'Calissanne' and 'Côte d'Ivoire' populations, behavior of the respective $M i$ virulent and avirulent populations was similar. No interaction between virulence to the $M i$ gene and the host's response to Prunus was observed in the two tested pairs of populations. This result establishes that the genetic systems involved in tomato ( $M i$ gene) and tested Prunus are not related.

\section{Literature Cited}

Barker, K.R. 1985. Design of greenhouse and microplots experiments for evaluation of plant resistance to nematodes, p. 103-113, In: B.M. Zuckerman, W.F. Mai, and M.B. Harrison (eds.). Plant hematology laboratory manual. Univ. of Massachusetts Agr. Expt. Stat., Amherst.

Bergé, J. B., A. Dalmasso, and M. Ritter. 1974. Influence de la nature de P'hôte sur le developpement et le déterminisme du sexe du nématode phytoparasite M. hapla, Comptes-rendes de l'Academic d'Agriculture de France, 2 Oct. 1974. p. 346-352.

Bernhard, R. 1962. Les hybrides prunier $\times$ pêcher et prunier $\times$ amandier: Principales caractéristiques, comportment comme porte-greffes éventuels du pêcher, p. 74-86. In: J.C. Garnaud (cd.). Advances in horticultural science and their applications. vol. 2. Pergamon Press, Oxford.

Bernhard, R., C. Grasselly, and G. Salesses. 1979. Orientation des travaux de sélection des porte-greffe du pêcher à la Station d'Arboriculture Fruitière de Bordeaux, p. 277-286. In: INRA, Station d'Arboriculture fruitière d Angers (cd.). Compte-rendu du symposium de la section fruits Eucarpia. Amelioration des arbres fruitiers. Angers, INRA.

Burdett, J. F., A.F. Bird, and J. M. Fisher. 1963. The growth of Meloidogyne in Prunus persica. Nematologica 9:542-546.

Chitwood, B. G., A.W. Specht, and L. Havis. 1952. Root-knot nematodes III. Effects of Meloidogyne incognita and M. javanica on some peach rootstock. Plant \& Soil 4:77-95.

Dalmasso, A. 1966. Méthode simple d'extraction des nématodes du sol. Rev. d'Ecol. Biol. du sol 3:473-478.

Day, L.H. and W.P. Tufts. 1939. Further notes on nematode resistant rootstock for deciduous fruit trees. Proc. Amer. Soc. Hort. Sci. 37:327-329.

Esmenjaud, D., C. Scotto La Massèse, G. Salesses, J.C. Minot, and R. Voisin. 1992. Method and criteria to evaluate resistance to Meloidogyne arenaria in Prunus cerasifera Ehr. Fundamental Applied Nematol. 15:385-389.

Esmenjaud, D., R. Voisin, J.C. Minot, G. Salesses, R. Poupet, and J.P. Onesto. 1993. Assessment of a method using plantlets grown from in vitro for studying resistance of Prunus cerasifera Ehr. (Myrobalan plum) to Meloidogyne spp. Nematropica 23:4148.

Felipe, A.J. 1989. Patrones para frutales de pepita y hueso. Ediciones Tecnicas Europeas, S.A. Barcelona, Spain.

Felipe, A.J., A.B. Blasco, M. Carrera, and R. Gella. 1989. 'Montpol' 645 y 'Montizo' 646: Nuevas selecciones clonales de "Pollizo" de Murcia. Information Tecnica Economica Agraria 83:41-46.

Fresno, A.P. 1975. Resistance of Prunus persica to Meloidogyne spp. Nematol. Sot. S. Africa Nwsl. 7: 12-13.

Havis, L., B.G. Chitwood, V.E. Prince, G.S. Cobb, and A.L. Taylor. 1950. Susceptibility of some peach rootstock to root-knot nematodes. Plant Dis. Rpt. 34:74-77.

Hirschmann, H. 1986. Meloidogyne hispanica n. sp. (Nematoda: Meloidogynidae), the "Sevilleroot-knotnematode". J. Nematol. 18:520-532.

Janati, A., J.B. Bergé, A.C, Triantaphyllou, and A. Dalmasso. 1982. Nouvelles données sur l'utilisation des isoésterases pour l' identification des Meloidogyne. Rev. Nematol. 5: 147-154.

Jarquin-Barberena, H., A. Dahuasso, G. de Guiran, and M.C. Cardin. 1991. Acquired virulence in the plant parasitic nematode Meloidogyne incognita. I. Biological analysis of the phenomenon. Rev. Nematol. 14:299-303.

Jenkins, W. R. 1964. A rapid centrifugal flotation technique for separating nematodes from soil. Plant Dis. Rpt. 48:692.

Kester, E.D. and R.N. Asay. 1986. 'Hansen 2168' and 'Hansen 536': Two new Prunus rootstock clones. HortScience 21:33 1-332.

Kester, E.D. and C. Grasselly. 1987. Almond rootstock, p. 265-293. In: R.C. Rom and R.F. Carlson (eds.). Rootstock for fruit crops. Wiley, New York.

Kochba, J. and P. Spiegel-Roy. 1975. Inheritance of resistance to the rootknot nematode (Meloidogyne javanica Chitwood) in bitter almond progenies. Euphytica 24:453-457.

Kochba, J. and P. Spiegel-Roy. 1976. 'Alnem 1', 'Alnem 88', 'Alnem 
201' almonds: Nematode-resistant rootstock seed source. HortScience 11:270.

Layne, R.E.C. 1987. Peach rootstocks, p. 185-216. In: R.C. Rom and R.F. Carlson (eds.). Rootstock for fruit crops. Wiley, New York.

Malo, S.E. 1967. Nature of resistance of 'Okinawa' and 'Nemaguard' peach to the root-knot nematode Meloidogyne javanica. Proc. Amer. Soc. Hort. Sci. 90:39-46.

Marull, J. and J. Pinochet. 1991. Host suitability of Prunus rootstock to four Meloidogyne species and Pratylenchus vulnus in Spain. Nematropica 21:185-195.

Marull, J., J. Pinochet, S. Verdejo, and A. Soler. 1991. Reaction of Prunus rootstock to Meloidogyne incognita and M. arenaria in Spain. J. Nematol.23:564-569.

Minz, G. and E. Cohn. 1962. Susceptibility of peach rootstocks to rootknot nematodes. Plant Dis. Rptr. 46:531-534.

Netscher, C. 1977. Observations and preliminary studies on the occurrence of resistance breaking biotypes of Meloidogyne spp. on tomato. Cahiers ORSTOM, Sér. Biol. 11:173-178.

Noe, J.P. 1985. Analysis and interpretation of data from nematological experiments, p. 187-196. In: K.R. Barker, C.C. Carter, and J.N. Sasser (eds.). An advanced treatise on Meloidogyne. vol 2. Methodology. North Carolina State Univ. Graphics, Raleigh.

Nyczepir, A.P. 1991. Nematode management strategies in stone fruits in the United States. J. Nematol. 23:334-341.

Orion, D. 1973. Studies on plant root-knot nematode interrelationships. Organisation Européenne pour la Procetion des Plantes/European Plant Protection Organization Bul. 9:67-71.

Philis, I. 1989. Resistance of peach seedlings to root-knot nematode attack. Intl. Nematol. Network Nwsl. 6:3-5.

Pinochet, J., J. Marull, and A. Felipe. 1991. Respuesta de patrones de melocotonero, ciruelo y cerezo de reciente introduction en Espana a Meloidogyne javanica. Nematropica 22:99-102.

Pinochet, J., J. Marull, S. Verdejo, and A. Soler. 1990. La seleccion de patrones de almendro, melocotonero e hibridos de melocoton $\times$ almendro frente a nematodos agalladores, Meloidogyne spp.. Fruticult. Professional 29:22-27.

Pinochet, J., S. Verdejo, and J. Marull. 1989. Evaluation de siete patrones de Prunus a tres especies de Meloidogyne en Espana. Nematropica 19:125-134.

Ramming, D.N. and O. Tanner. 1983. 'Nemared' peach rootstock. HortScience 18:376.

Renaud, R., R. Bernhard, C. Grasselly, and F. Dosba. 1988. "Diploid plum $\times$ peach hybrids" rootstock for stone fruits. HortScience 23: 115-1 17 .

Roberts, P. A., A. Dalmasso, G.B. Cap, and P. Castagnone-Sereno. 1990. Resistance in Lycopersicum peruvianum to isolates of Mi gene-compatible Meloidogyne populations. J. Nematol. 22:585-589.

Scotto La Massèse, C. 1989. Les problèmes posés par les nématodes phytophages à 1'amandier. Options Méditerranéennes, Sér. Séminaires 5:33-38.

Scotto La Massèse, C.,D. Esmenjaud, J.C. Minot, and R. Voisin. 1990. Host suitability in the genus Prunus to Meloidogyne arenaria, particularly clones and intraspecific hybrids of $P$. cerasifera. Acts Hort. 283: 275-284.

Scotto La Massèse, C., C. Grasselly, J.C. Minot, and R. Voisin. 1984. Difference de comportment de 23 clones et hybrides de Prunus à l'égard de, quatre espèces de Meloidogyne. Rev. Nematol. 7:265-270.

Sharpe, R.H. 1957. Okinawa peach shows promising resistance to rootknot nematode. Proc. Florida Hort. Soc. 70:320-322.

Sharpe, R. H., and V.G. Perry. 1967. Root-knot nematode populations on peaches in Florida. Proc. Florida State Hort. Soc. 80:342-344.

Sharpe, R. H., C.O. Hesse, B.A. Lownsberry, V.G. Perry, and C.J. Hansen. 1969. Breeding peaches for root-knot nematode resistance. J. Amer. Soc. Hort. Sci. 94:209-212.

Sherman, W.B. and P.M. Lyme. 1983. Improvement of peach rootstock resistant to root-knot nematodes. Pmt. Florida State Hort. Soc. 96:207-208.

Sherman, W. B., P.M. Lyrene, and P.E. Hansche. 1981. Breeding peach rootstock resistant to root-knot nematode. HortScience 64: 523-524.

Triantaphyllou, A.C. 1981. Oogenesis and the chromosomes of the parthenogenetic root-knot nematode Meloidogyne incognita. J. Nematol. 13:95-104.

Tufts, W.P. 1929. Nematode resistance of certain peach seedlings. Proc. Amer. Soc. Hort. Sci. 26:98-100.

Wallace, W.P. 1969. The influence of nematode numbers and of soil particle size, nutrients and temperature on the reproduction of Meloidogyne javanica. Nematologica 15:55-64. 